IRSH 52 (2007), pp. I I6-I 23 DOI: I0.1017/S0020859006002835

(C) 2007 Internationaal Instituut voor Sociale Geschiedenis

\title{
Beyond the Atlantic: Connecting Migration and World History in the Age of Imperialism, I840-1940
}

\author{
UL B E B OS M A
}

The age of mass migration that commenced in the I 840 s has traditionally been conceived within the orbit of Atlantic history, and rendered as a narrative of modernity and industrialization. At an individual level the departure for the New World was propelled by rising expectations, which nicely fitted the macro-pattern of converging labour markets between North-America - as well as Australia for that matter - and Europe. Many of the assumptions that brought global migration under the aegis of modernization have been refuted, or at least seriously questioned. But that still leaves us with the important question whether there are alternative paradigms available that fit the realities both within and outside the North Atlantic world. Some have already answered the question negatively. According to Hatton and Williamson, it is impossible to find a unifying paradigm that would enable us to develop a global migration history. Their argument is too important not to be cited:

[...] what is now known as the Third World [...] were segmented by discrimination, language, and custom. They were segmented by long distance and high costs. They were segmented by the poverty of the Third World laborsurplus areas, areas so poor that potential emigrants would have found it impossible to finance the move to the booming OECD labor markets anyway. ${ }^{\mathrm{I}}$

Before dealing with the question of how this segmentation was brought about, let us accept for the moment that the North Atlantic and peripheral migration flows were part of different economic systems and of different migration regimes. No doubt, in the course of the ninteenth century, migration flows became more and more subject to regulations with implicit and often even explicit racial overtones. These facts seem to substantiate the normative approach taken by Hatton and Williamson. Starting from the elegant and ideal world of economic analysis, an image emerges of white European migration that is pure and homogeneous like clean water, flowing to those parts of the world where the highest incomes could be earned. And here is where the argument goes wrong. 
Though, from a European perspective, the North Atlantic migration was singular in terms of sheer numbers in the second half of the nineteenth century, free white (labour) migration was historically far from universal. Even in the age of mass migration millions of European migrants went under state-sponsored conditions or ended up in semi-indentured conditions. The elegance of a world of economic freedom, which apparently implies the free movement of labour, is a rare commodity in the real world.

Let us now return to the question of the causes of segmentation of labour markets and their concomitant compartimentalization of migration flows. These did not emerge naturally, but involved numerous government decisions to control migration. My contention would be that these mechanisms of control were, consciously or unconsciously, increasingly navigated by a social Darwinist mindset. What I mean is the implicit or explicit assumption that there is a "hierarchy of human races" in terms of their propensity to operate in modern civilization. In this hierarchy black labour was enslaved, Asian labour indentured, whereas the apex was firmly held by the free white well-educated northern European. Since government decisions were informed by this racial taxonomy, it became ingrained in migration history.

Take, for example, Australia which around 1900 closed its borders for Polynesian and Chinese labour, turning to Mediterranean Europeans for the production of "white" cane sugar. ${ }^{2}$ Or another example: Cuba closing its borders in 1902 for Haitian and Jamaican labour, turning to the import of Spanish workers. ${ }^{3}$ Thus, immigration restrictions shored up the distinction between the Old World and its (former) settler colonies on the one hand and the messy world of exploitation colonies on the other. Free Asian intercontinental migration, which did not fit into this distinction, was either ignored or systematically underrated, as McKeown argues. There was far more non-indentured Chinese and Indian migration than indentured. Only a fraction (Io per cent) of the total of 30 million Indian overseas labour migrants, according to the old but still excellent book of Davis, went in indentured conditions. ${ }^{4}$ Free intercontinental migration is not a European prerogative.

The sediments of late nineteenth-century racial prejudice nicely square with historical markers that are more or less a derivative of the immigration history of the United States. The 1846-1924 age of mass migration to the United States was a unique and defining moment in the understanding of free labour and the freedom of movement. Western

2. A.A. Graves, Cane and Labour: The Political Economy of the Queensland Sugar Industry I862-I906 (Edinburgh, I993), pp. 47-48, 60-6I.

3. Alejandro de la Fuente, "Two Dangers, One Solution. Immigration, Race and Labor in Cuba, 1900-1930", International Labor and Working-Class History, 5 I (1997), pp. 30-49.

4. Kingsly Davis, The Population of India and Pakistan (New York, I95 I), pp. 99-100. 
understanding of race, labour, and migration became subject to an epistemic shift. Though there is no such thing as a unilinear and homogeneous development towards "scientific or biological racism", there seems to be consensus that a "biological" type of racism emerges in the mid-nineteenth century. 5 The way in which the political economy of colonialism, its ensuing divisions of labour, and "scientific racism" are connected is an important debate in itself. What concerns us here is how it played out in the age of mass migration.

New demarcations and a new sense of geographical domains came into existence. As Thomas Holt argues, it is only around I850 that the distinction emerges between white settler colonies versus tropical exploitation colonies where white migrants were only sojourners. Before I 846 the distinction would have been hardly relevant. It was only at the time of the California gold rush and the Irish potato blight that the number of US immigrants exceeded the magical I००,०००. From then onwards free migration became the norm, as appears from the regulations and monitoring authorities imposed upon recruiting practices and shipping of migrants. It is no coincidence that statistics about intercontinental migration begin to appear in the early years of the age of mass migration, as governments become aware of its significance and repercussions.

The mid-nineteenth century marked the beginning not only of mass migration but also of "new colonialism" and concomitant to that of fifty years of intensive indentured migration. ${ }^{6}$ By observing that before i 850 the distinction between settler and exploitation colony did not have much of a meaning, Thomas Holt makes us aware of the fact that "settler" and "exploitation" are not concepts outside human history, but produced by migration histories and pertaining to migration regimes, which changed over time. Indeed, the Eurocentric content of the categories "settler" and "exploitation" goes largely unnoticed. Settler colonies are white, but should they be by definition? Manchuria absorbed millions of Chinese settlers and Liberia was a black settler colony, for example, and yet we still consider settler colonies as territories to be populated by white free migrants, looking for their land of opportunities. "Whiteness" and "freedom" are both contested categories in this context. In spite of the fact that new

5. Matthew Fryre Jacobson, Whiteness of a Different Color: European Immigrants and the Alchemy of Race (Cambridge, I988), p. I3; Theodore W. Allen, The Invention of the White Race, I, Racial Oppression and Social Control (London, 1994), pp. 21, 32; Thomas C. Holt, The Problem of Freedom: Race, Labor and Politics in Jamaica and Britain, I832-1938 (Baltimore, MD, 1992), p. 236; Roxanne Wheeler, The Complexion of Race: Categories of Difference in Eighteenth Century British Culture (Philadelphia, PA, 2000), p. 38; Waltraud Ernst, "Introduction", in idem and Bernard Harris (eds), Race Science and Medicine, I700-1960 (London, 1999), pp. I-29.

6. David Northrup, Indentured Labor in the Age of Imperialism I834-I922 (Cambridge, I995), p. 2 I. 
colonialism nicely coincided with the shift from slave trade to indentured labour migrations, it did not marginalize the phenomenon of (white) indentured and government-assisted labour. The white immigration regimes of Latin American countries like Brazil or Argentina or Queensland, Australia were to reproduce the white dominance of their societies, as was the case for Cuba but also for Brazil, where some kind of demographic balance existed between those segments of the populations that were considered to be white and Creole and those considered to be black. ${ }^{7}$

Historical markers of course can change the game and this is definitely the case with migration history. Usually, the year I 846 is taken as a starting point and 1924 as the end of the era of mass migration. The first year is a defining moment in Western migration history and in European colonial expansion, and therefore a rather Atlantic-centric marker, but one could argue for it, because it certainly impinged upon the world at large. To use the year 1924, however, as a marker to end the age of mass migration makes far less sense from the perspective of global migration history. The only reason why the year 1924 became part of migration historiography is that by that time the United States had issued its Immigration Act, which put quota restrictions mainly for immigrants from southern and eastern Europe in place. The consequence is, however, that not only the numbers of European migrants to the US are overstated at the expense of European migrations to other parts of the world, but that intercontinental movements within other migration regimes are underrated as well, as McKeown has excellently demonstrated. ${ }^{8}$

After 1924, millions of Europeans went to Latin America, the British dominions, and European colonial possessions. In the period I 846-1924 about 80 per cent of the European migrants for the western hemisphere went to the US. Taking 1940 , the proportion would be 65 per cent: 36 million out of a total of 55 to 58 million. If we add some easily accessible data of Willcox and Ferenczi between I 846 and I940, we could argue that European migration to destinations in Canada, Latin America, Africa, and Asia more or less equals the United States. If 36 million migrants went to the United States, at least another 20 million went to Latin America and the Caribbean, whereas another 6 million crossed the Urals for Siberia between I80I and I9I4 alone. About I.5 to 2 million migrants went to Australia and probably the same number departed for South Africa. ${ }^{9}$ In

7. Lilia Moritz Schwarcz, The Spectacle of Races: Scientists, Institutions and the Race Question in Brazil I870-1930 (New York, 1993), pp. 10-1 I.

8. Adam McKeown, "Global Migration", Journal of World History, is (2004), pp. I 55-190.

9. François-Xavier Coquin, La Sibérie. Peuplement et immigration paysanne au XIX siècle (Paris, 1969), pp. 747-749; Donal Treadgold, The Great Siberian Migration: Government and Peasant in Resettlement from Emancipation to the First World War (Princeton, NJ, 1957), p. 34. For South Africa, see Walter F. Willcox and Imre Ferenczi, International Migrations (New York, I929-I93 I), I, p. I053. 
addition, according to Ferenczi and Willcox, between 5 and 6 million Europeans traveled to north Africa in the late ninteenth and early twentieth centuries. ${ }^{10}$ Last but not least, a yet uncounted number of colonial soldiers were sent overseas: veterans populated Algeria, and in colonies like the Dutch East Indies and Cuba with strong colonial garrisons 20 to 30 per cent of military stayed after their term. ${ }^{\text {II }}$ These numbers seem to imply a drastic reduction of the United States as migration destination for Europeans: only half of the European intercontinental migrants went to the United States in the age of mass migration.

No doubt, counting global migration flows involves a lot of comparing apples with oranges. For North Africa it is almost impossible to gauge the migration figures, because of the proximity of France and Spain on the one hand and Morocco and Algeria on the other. But this should not deter us from arriving at a more precise picture of the diversity of the European emigration flows, as it directly relates to the assumption that European intercontinental migration in the age of mass migration was overwhelmingly free, and that other migrations are taking place outside this freedom.

First, we have to include the millions of European state-sponsored and often more or less indentured labourers to Latin America, Cuba, and Australia in the course of the ninteenth century. Second, we need to add the millions of colonial soldiers, and the millions who crossed the Urals in unfree conditions. It would bring back Russia in the family of colonizing states, as this intercontinental migration was part and parcel of Russian imperialism. Thirdly, it would help us to consider the frequent occurrance of all types of informal indentureship in white frontier regions in western North America not as a anomaly but more as one of the common features of migration history. ${ }^{\mathrm{I}}$ It is obviously impossible to define in the middle of a debate what intercontinental means. Sometimes it is just a few hundred miles, as is the case with the distance between France and Algeria, but it can also be on other side of the world, as is the case with Australia. That does not, however, constitute a case against bridging the gap between studies on free white migration and European colonialism, which have long been considered as two separate realms.

I0. For migration figures to Algeria, Morocco, and Tunisia, see Willcox and Ferenczi, International Migrations, I, pp. 203, $1028-1037$. This book does not provide reliable figures for Egypt and Libya, but we may expect that migration flows to these countries are comparable to those for Morocco and Tunisia. For Algeria, note that Willcox and Ferenczi mention 4,588, 184 travellers from Europe entering this colony between I893 and 1924, whereas net migration over the same period amounted to just 29,583 .

I I. Ulbe Bosma, "Sailing through Suez from the South", International Migration Review, forthcoming.

I2. Gunther Peck, Reinventing Free Labor: Padrones and Immigrant Workers in the North American West, I880-1930 (Cambridge, 2000). 
Outside the world of the Atlantic, moreover, European migrations flows are often no longer the dominant ones, either in terms of numbers or in terms of economic power. It is in the sphere of colonialism that the intersection between different migration regimes becomes most visible and where we can build upon a long and rich historiographical debate on Eurocentric and Asia-centric perspectives on trade and migration. In the I 930 s this debate was started by the Dutch sociologist J.C. van Leur, who argued that up to the beginning of the ninteenth century Asian and European trade were on equal footing in Asia. Though this might be an overstatement - one cannot underrate the power and the administrative and organization muscle of the Dutch East Indies Company and later on the colonial administration - there has always been room for extensive intra-Asian trade and migration outside the orbit of the Dutch colonial economy. ${ }^{13}$ Chinese migration began long before the Europeans came to south-east Asia and grew alongside European migration, as Denys Lombard, Claudine Lombard-Salmon, and others have argued. ${ }^{14}$

Coming to terms with the existence of different migration regimes and histories does not necessarily mean a fragmentation of migration history in a series of discrete paradigms. Rather the opposite might be true: by identifying different migration regimes we will probably become much more aware of path dependency in migration history. The migration curve used by Williamson has the undeniable virtue that it identifies a rhythm, which might be universal. ${ }^{\text {Is }}$ The only caveat is that this curve towards equilibrium is just a chunk of the rhythm of mass migration, cutting off the pioneering phase after the frontier has been conquered. In this phase, indentureship was not just a function of distance, the lot of the insolvent labour migrants who had first to work off their fare, it was also a powerful means to further imperial interests, precisely at a time when ever more spaces in the world became involved in global commodity production. Every settlement - take America, Canada, Australia, Algeria, Siberia, or Manchuria - knew their initial phases of state-engineered migration. Australia and Siberia are outstanding examples of colonies that were created by deportation of convicts followed by state-assisted

13. M.A.P. Meilink-Roelofsz, Asian Trade and European Influence in the Indonesian Archipelago Between I500 and About I630 (The Hague, 1962), pp. 25-26; Gerrit Knaap and Heather Sutherland, Monsoon Traders: Ships, Skippers and Commodities in Eighteenth-Century Makassar, Verhandelingen 224 (Leiden, 2004), pp. I71-I73.

I4. See, for example, Denys Lombard, Le carrefour javanais, 3 vols (Paris, I990-1991) or Claudine Salmon, "The Han Family of East Java: Entrepreneurship and Politics (18th-19th Centuries)", Archipel, 4I(199I), pp. 53-88. For the role of the Chinese immigrants and trading houses in the twentieth-century marketing of sugar, see Peter Post, "The Kwik Hoo Tong Trading Society of Semarang, Java: A Chinese Business Network in Late Colonial Asia”, Journal of Southeast Asian Studies, 33 (2002), pp. 279-296.

I5. Timothy J. Hatton and Jeffrey G. Williamson, The Age of Mass Migration: Causes and Economic Impact (New York, I998), p. I3. 
migration. ${ }^{16}$ Moreover, the gradual phasing out of "heavy indentureship" to more informal ways of bondage through private recruitment agencies was a universal phenomen. ${ }^{17}$ Probably all major migration movements did start in indentureship. While the image of the free pioneer is powerful, the lived experiences are those of the indentured labourers.

From imperialism and unfree labour we can move on to the very important point that increasing flows of goods and capital was not attended by an increasing freedom of labour. On the contrary, migration restrictions were increasing and, as Sabyasachi Bhattacharya has argued, there was still considerable movement of unfree labour. ${ }^{18}$ It is the contradictory phenomenon that in the late ninteenth and early twentieth centuries a highly globalized world in economic terms emerged, to which some refer as the first phase of globalization (from the viewpoint of global migration history, the old word imperialism is far more accurate). Between I 890 and I9I 3 migration was heavily manipulated and became also increasingly directed within empires. For example Dutch colonial government in Surinam shifted from Indian to Javanese coolies in I 894, and from Chinese to Javanese for its plantations in Sumatra in I9I I. But also, as far as European migration was concerned, a shift from the United States to the empire was clearly visible in countries like the Netherlands and Great Britain. ${ }^{19}$

To conclude: in order to move beyond the Atlantic world and to connect migration and world history, we need to understand the influence of social Darwinism and its ensuing hierarchy of labour, in which white is on top and other labour markets are segmented, but always with Europeans in control. From the perspective of outside the Atlantic, the age of imperialism was, to a large degree, a process of carving out a white existence, by dividing the world between the domains of white rule and the domains where whites lived in freedom. During this process historians in the West have lost sight of other simultaneous massive migration movements in Asia, which would definitely have moved beyond Asia in far greater numbers if Western countries had not imposed their restric-

16. For Siberia, see the classic work of George Kennan, Siberia and the Convict System (New York, I891) and for Australia, Robin F. Haines, Emigration and the Labouring Poor: Australian Recruitment in Britain and Ireland, I83I-I860 (Basingstoke, 1997).

17. Northrup, Indentured Labor in the Age of Imperialism, pp. 21, 44, I44. See also McKeown, "Global Migration", p. I 58.

I8. Sabyasachi Bhattacharya, "International Flows of Un-free Labour", in K.S. Jomo (ed.), Globalization Under Hegemony: The Changing World Economy (New Delhi, 2006), pp. I95226, 222. See also Tom Brass and Marcel van der Linden (eds), Free and Unfree Labour: The Debate Continues (Berne, 1997).

19. Robert P. Swierenga, "The Delayed Transition from Folk to Labor Migration: The Netherlands, I 880-I920", International Migration Review, 27 (1993), pp. 406-424, 420; W.A. Carrothers, Emigration from the British Isles: With Special Reference to the Development of the Overseas Dominions (London, 1929), pp. 242, 313. 
tions. The fact that millions of European migrants ended up in indentured conditions in places like Sao Paulo or Siberia, or informally indentured (as in North America's West) should not be treated as an anomaly of the age of mass migration but as part of the same process, namely to shore up the "whiteness" of these territories. Finally, I think that we should not argue too much about the numbers, as they only have meaning within the context of clearly defined argument. Numbers should help us to be critical about fixed images of the past and help us to develop paradigms and concepts that can apply to different migration regimes and different eras, without privileging one particular region in the world. 